sites in the Gorge, from all the beds, with their nature, stratigraphic position, industry, date of discovery and date of excavation if excavated. Following the text are some admirably clear photographs, and tucked inside the back cover are several large fold-out plans and a section, including DK, FLK (Zinjanthropus site), FLK North and FLK NN.

The whole book, it will be seen, is thus essentially a straightforward and lucid exposition of a large body of archaeological data of outstanding interest and importance, together with an opening contribution, as it were, to the discussion which will last for many years. It certainly does not contain, nor is it intended to contain, the last word on any aspect of the specialist study or wider comparison of the finds. Much more remains to be done in a great number of ways, before it can be said that the finds from Olduvai Gorge Beds I and II have been fully described and understood in their complete African and world context. This could even take another forty years, and does not depend only on work at Olduvai. But what a foundation there is now on which to build!

DereK RoE

\section{A Shameful Tale}

Mato Grosso: Last Virgin Land. By Anthony Smith. (An account based on the Royal Society and Royal Geological Society expedition to Central Brazil. 1967-9). Pp. 288 (200 photographs). (Michael Joseph: London. 1971). £5.

THIS is a sad book; it tells of the impending destruction of the largest area of primaeval forest remaining in the tropics. The taming of this vast wilderness is inevitable under the pressure of growing human populations, but it is not being done with care after gaining the information necessary for conservative planning. The country is not being developed but exploited, with the aid of the internal combustion engine on wheels and on wings, in the most ruthless and thoughtless manner at the behest of absentee millionaire landowners anxious to grasp at yet more money. It is a shameful tale.

Some Brazilians have long hankered after a grandiose new Federal Capital -Brazil is a federation of United States-to supersede Rio de Janeiro as the seat of government. Now they have Brasília in the State of Goiás, a fantasia of "modern" buildings set in country until recently inhabited only by a few Indians and squatters. In 1965 the Brazilian authorities began building a road through the adjacent State of Mato Grosso as part of a great South American system of highways that was to reach the Amazon River in the north; some of it is finished, but many thousand miles remain to be built.

The Brazilian Government invited several countries to send teams of scientists to study the territory near the new road while it was still unchanged. In response the Royal Society and the Royal Geographical Society sent a joint expedition, which set up a base camp 500 miles from Brasília at a place where the forest was practically undisturbed by man and his animals. In the course of two years forty-four British and twenty Brazilian scientists worked at the temporary field station, few of them for more than six months and many for shorter terms. Here, in a 20kilometre-square sample area of the thousands of square miles of mato, the workers on zoology, botany, soil science, medicine, and geography carried out their researches, which in virgin country such as this were necessarily descriptive rather than experimental in the short time available.

$\mathrm{Mr}$ Smith, a journalist trained in zoology, was commissioned by the sponsors of the expedition to write this official account of the enterprises. It is based on three visits to Mato Grosso between 1967 and 1969, and gives an excellent picture of the country, its inhabitants, and of the day-to-day work of the scientists, with understanding, humour, and sympathy. Most of the visiting scientists not only carried out work of great value but enjoyed their experiences in this naturalist's paradise in spite of the usual insect and other discomforts of the undeveloped tropics. Although they could only scratch the surface, the information they collected is essential to developers and if it "is not heeded by them, disaster may befall not only the natural environment, but also the people concerned, be they peasants or labourers, capitalists or politicians". Everything the author says about the exploitation of the country suggests that it will not be heeded, for the exploiters know nothing and care less about rational conservation and development. It was hoped that the base camp could become a permanent research station, but with changes of official policies and persons-Brazilian politics are ever unstable-which led to many earlier troubles, it had to be abandoned, "evacuated", and left for the caboclos, the squatters liable to be dispossessed at any moment, picking over the pathetic rubbish to salvage what they could find.

The exploiters, who bought ranches of half a million acres or more, that were to them merely squares on a map, for the equivalent of a few pence an acre, seem to be the natural successors of the Indian Protection Service. The Service, which looked on the Indians as vermin, was dissolved in 1967 for the wholesale slaughter of its protégés "by dynamite, machine guns, or sugar laced with arsenic". The only redeeming feature of this dreadful story is the gallant work of the brothers Villas Boas among the Indians in the recently made Parque Nacional do Xingú. The outlook for the Indians is bleak: "The resistance of the formerly invincible tribes seems to disintegrate the moment their vulnerability has been proved. They would die without effort, or just vanish." The picture on the book-jacket of the heir to the chief of a tribe reduced to fifty-three persons, lying listlessly in his hammock gazing into a hopeless future, too apathetic to brush away the fly on his arm, epitomizes the plight of the Amerindians.

The book is lavishly illustrated with photographs of the greatest beauty and interest, most of them in colour, taken by professional photographers specially commissioned for the work. Everything about this magnificent book, recording the results of British enterprise, is of the highest standard. It is printed in Japan. L. HARRISON MATTHEWS

\section{Early Eastern Europeans}

Hunters, Fishers and Farmers in Eastern Europe: 6000-3000 BC. By Ruth Tringham. Pp. $240+12$ plates. (Hutchinson University; December 1971.) $£ 2.50$ cased; $£ 1.50$ paper.

THIs book contains four sections: (i) the environmental background, (ii) post-glacial hunting and gathering communities, (iii) the earliest foodproducers, $5500-3800 \mathrm{BC}$, and (iv) economic development and the earliest use of metal, 3800-3000 BC. These with the title indicate the scope of the book. The material will probably be unfamiliar to non-specialists, and has considerable intrinsic interest, so that the reader of Nature might be urged to take it up on that account ; the principal part of its value for archaeology students lies in the descriptions and in the quite extensive references after each chapter. The main criticisms arise not from points of fact so much as from the nature of some of the interpretations offered, and the impression both kinds of reader might conceive of contemporary archaeology. Many people will not be satisfied with the explanatory value of "acceptance" against "rejection", or "conservation" against "innovation", on a background of diffusion. Similarly not many anthropologists will like a "change in village type caused by a modification of the social structure" (page 72), or by a "change in economy" (page 116), on the available evidence. The environmentalist may find the first section 